\title{
Validation of a French adaptation of the Multidimensional Student's Life Satisfaction Scale in its abbreviated form, for 5- to 11-year-old children with and without intellectual disability
}

\author{
Charlotte Coudronnière ${ }^{a}$, Fabien Bacro ${ }^{a}$, Philippe Guimard ${ }^{a}$ and Jean-Baptiste Muller ${ }^{b}$

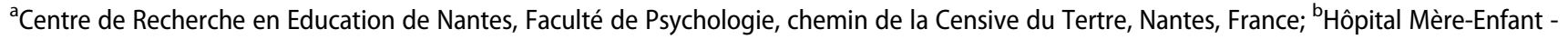 \\ 4ème étage Néonatologie \& Réanimation Pédiatrique, CHU de Nantes, Nantes, France
}

\begin{abstract}
Background: The quality of life (QOL) of children with and without intellectual disability (ID) has become a growing concern in the literature but the QOL instruments are not adapted for use with young children and children with ID. The objective of this study was to validate a French adaptation of the abbreviated form of the Multidimensional Student's Life Satisfaction Scale (MSLSS).

Method: Confirmatory factor analyses were conducted on the data collected from 411 children aged between 5 and 11 years old. Internal consistency, test-retest fidelity, and convergent validity were tested.

Results: The preliminary results of this study show that the model fitted the data collected to assess the life satisfaction of children, $X^{2}(395)=705.340 ; p<.001 ; \mathrm{CFI}=0.911 ; \mathrm{TLI}=0.902 ; \mathrm{RMSEA}=0.044$. Very good levels of internal consistency were obtained for both children with and without ID, with coefficients ranging from 0.70 to 0.88 . The test-retest coefficients calculated after a 2-week interval highlighted a moderate (coefficients lower than 0.70 ) to weak temporal stability, which seemed more pronounced in children with ID.

Conclusion: Despite some limitations, this instrument could be very useful for childhood professionals. It will enable them to assess the perception that children have of their wellbeing in the perspective of promoting their QOL. This scale also provides researchers in psychology with the opportunity to enrich their knowledge on the QOL of children with ID.
\end{abstract}

KEYWORDS

children with intellectual disability; quality of life; wellbeing; life satisfaction scale; French validation; selfassessment

\section{Introduction}

In recent decades, the QOL of people with disability has become a growing concern in the literature and in Anglo-Saxon countries (Magerotte, 2013). In the intellectual disability (ID) field, Anglo-Saxon practices support the promotion of a lifestyle of comparable quality to that of people with a typical development. Thus, everyone with ID should be able to fulfil valued social roles (pupil, student, etc.) and be considered a full citizen (Proulx, 2008).

In parallel, since the 2000s with the emergence of positive psychology, QOL has become a central subject of study for many disciplines, particularly those dedicated to childhood (Seligman \& Csikszentmihalyi, 2000). This new field of research sees the QOL of individuals from the angle of subjective wellbeing in order to favour their personal thriving (Shankland, 2014). In the ID field, subjective wellbeing constitutes a central subject of study for social policies and the delivery of services. It forms the basis for the development of new policies as well as the assessment of educational programs and their readaptation with the primary objective of increasing the life satisfaction of children with ID (Proulx, 2008). According to the model of Diener (1984), the subjective wellbeing of an individual relies on the affective and cognitive assessment of his or her life and is characterised by the frequent experience of positive affects, a low level of negative affects, and a high feeling of satisfaction with his or her life. Where the affects fluctuate and have a limited existence over time, life satisfaction is more stable and represents the "cognitive-evaluative" dimension of subjective wellbeing. This dimension is considered a key determinant of subjective wellbeing (Diener, Lucas, \& Oishi, 2002).

\section{QOL instruments for children}

The subjective concept of QOL has led many researchers to consider that children are best placed to express their feelings and assess their wellbeing (Upton, Lawford, \& Eiser, 2008). However, various authors emphasise that the limited cognitive and language abilities of these 
children mean that their replies are marred by a number of biases: a tendency to acquiescence and social desirability, difficulty in assessing the subjective aspects, or in understanding the items. As a result, there are few scales designed for children under 8 years old (Rodary, PezetLangevin, \& Kalifa, 2001). Moreover, to our knowledge, no instrument has been developed or adapted for children with ID.

In addition, the QOL instruments currently available were mostly developed in the paediatric field. Their primary objective is to study the impact of the illness on the QOL of sick children (Rodary et al., 2001). As a result, the dimensions linked to health and functional abilities are overrepresented in these questionnaires, which limits the place of other dimensions describing the subjective QOL of children in good health (Bruchon-Schweitzer, 2002). Moreover, as they are often inspired by instruments designed for adults, the dimensions of QOL covered by these questionnaires only partially describe the subjective QOL of children. Research has shown that peers, family relationships, and the school environment occupy an important place in the life of children (Coudronnière, Bacro, Guimard, \& Florin, 2015). Yet these life domains are measured in a limited way in these instruments (Matza, Swensen, Flood, Secnik, \& Leidy, 2004). In addition, most of them take the form of hetero-questionnaires, asking the opinion of the members of the child's family (Eiser \& Morse, 2001). However, without knowledge of all the life experiences of children and the way they understand them, the third parties produce assessments that do not reflect the feelings and experiences of children (Rajmil et al., 2009; Upton et al., 2008). Lastly, the psychometric qualities of these instruments have not always been tested or may be questionable (Rodary et al., 2001). Most of them have been developed in English-speaking countries and very few French instruments are available (Siméoni, Auquier, Delarozière, \& Béresniak, 1999). Table 1 presents four generic self-assessment scales currently available for young children from 5 years old.

Ultimately, the QOL instruments currently available are not adapted for use with very young children and children with ID. The study of their QOL and the development of generic self-assessment tools require more research, particularly in French-speaking countries. It should also be recalled that the QOL of children with special needs is composed of the same dimensions as that of children without disability (Magerotte, 2013). It is therefore essential that future tools assess the QOL of children without disability and children with ID in the same way and by collecting their point of view directly.

Providing this type of scale for childhood professionals and psychologists would enable them to assess the educational and therapeutic actions offered to children in order to improve their wellbeing (Proulx, 2008). Giving children the opportunity to express themselves regarding the decision processes that concern them would lead to a better understanding of their expectations and an assessment of the relevance of their psychotherapeutic and educational care. In addition, it would enable practitioners to identify areas that can be sources of problems in the lives of children (Lemétayer \& Gueffier, 2006). Finally, such instruments could enable researchers to enrich the current theoretical knowledge on the wellbeing of children with ID, to understand better the factors that influence it, and to examine its role in children's later development (Magerotte, 2013).

\section{The MSLSS in its abbreviated form (Huebner, Zullig, \& Saha, 2012)}

For these objectives, the abbreviated form of the MSLSS seems particularly relevant. In fact, this instrument assesses the QOL of children by measuring their life satisfaction. In 1994, the original form was composed of 40 items (Huebner, 1994). However, in order to simplify the content of the scale, the format of the questionnaire was reduced to 30 items by eliminating the items formulated negatively (Huebner et al., 2012). Due to its generic component and self-assessment format, it can be used to collect directly the point of view of healthy and sick children. Designed for children aged from 8 to 18 years, this scale measures their general QOL as well as their satisfaction in specific domains identified as central in the discourse of children aged from 5 to 11 years (Coudronnière et al., 2015). Lastly, it has satisfactory psychometric properties. It was validated with a population of 844 pupils aged 13 to 15 years living in south-east United States. Confirmatory analyses highlighted the structural validity of the model (Huebner et al., 2012). The convergent and discriminant validities were not tested for the abbreviated version of the MSLSS. Nevertheless, the 40-item scale presented good convergent validity with measures of affectivity, wellbeing, and feeling of self-efficacy (Gilman, Huebner, \& Laughlin, 2000) and was also negatively correlated with scales of depression and anxiety (Funk, Huebner, \& Valois, 2006).

The abbreviated form of the MSLSS presents a number of advantages for use with very young children and children with ID in a French-speaking context. Nevertheless, currently validated with a population of children without disability aged 8 to 18 years, the present format of the questionnaire is not adapted to the abilities and life context of children younger than 8 years old or children with ID. 


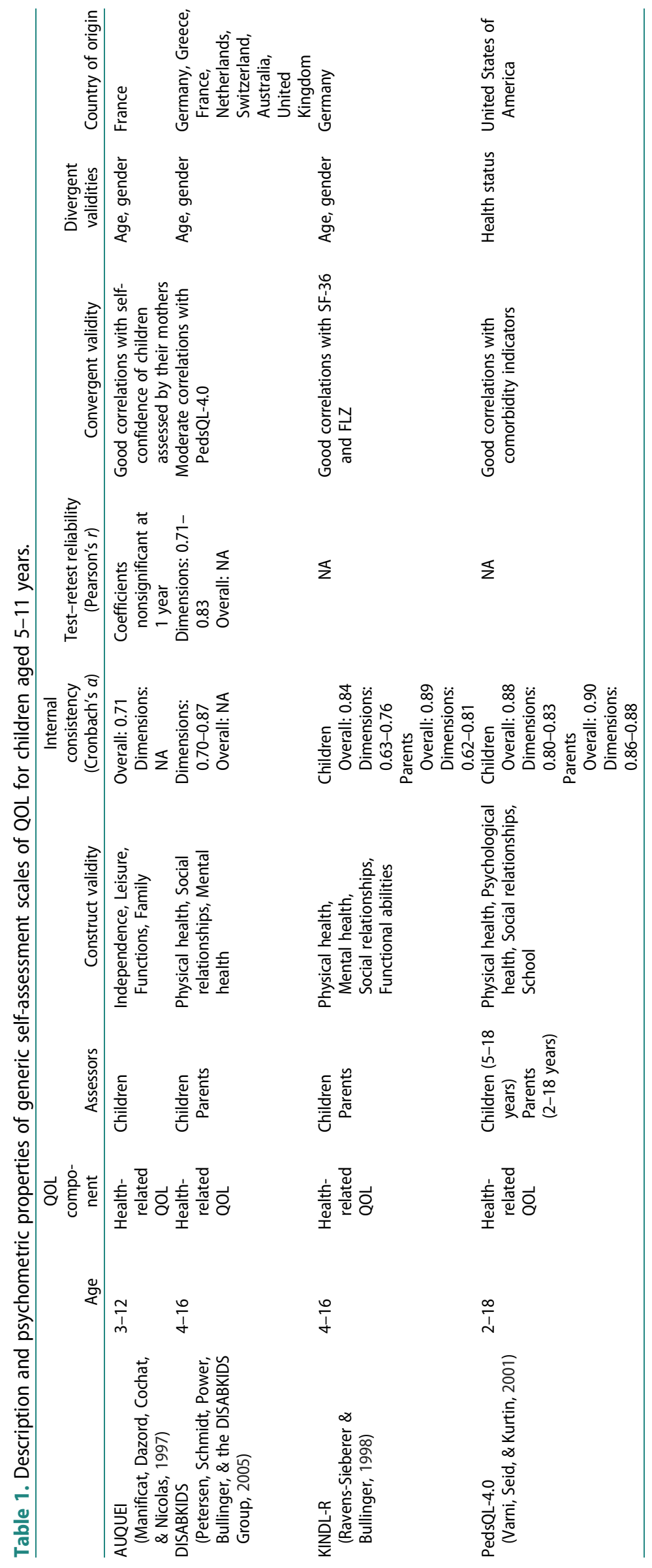


Some recommendations for adapting QOL instruments to very young children and children with ID

Different studies have proved that these children are capable of giving a reliable estimation of their QOL and expressing their emotional states, which vary according to their experience or understanding of events in their daily life (Lemétayer \& Gueffier, 2006). In the paediatric sector, self-assessment scales have been developed to measure the perception of pain in children without disability. Overall, authors state that from the age of 5 years, the cognitive abilities of children allow them to understand and agree to the formulated request (Stinson, Kavanagh, Yamada, Gill, \& Stevens, 2006). Nevertheless, certain developmental characteristics must be taken into account to adapt the questionnaires to their abilities (Matza et al., 2004). Before the age of 7 years, children have limited abilities in reading and writing that can compromise their self-assessment (von Baeyer, Forsyth, Stanford, Watson, \& Chambers, 2009). Thus, it is advisable to use an external examiner to read and fill in the questionnaire (Ravens-Sieberer et al., 2014). Moreover, to limit all confusion about meaning, the formulation of the items must be as clear as possible and the mode of questioning must involve no ambiguity, with no negative interrogative forms (Eiser \& Morse, 2001). Concerning the format of questionnaires, Likert scales are very often used to assess pain intensity. Skills in the counting, seriation, and classification of numbers are required to discriminate between the different answers proposed. Before 7 years, these abilities are not yet mastered and children tend to deal with the choice of items in a dichotomic way (Chambers \& Johnston, 2002). In contrast, the scales of drawn faces seem more adapted as the images represent the different choices of answers. It also appears that rounded shapes are dealt with better than square or rectangular ones. Thus, from the age of 4 years, children succeed in giving precise and valid answers (von Baeyer et al., 2009).

The aim of this study was to validate our adaptation of the abbreviated form of the MSLSS for children without disability and children with ID aged from 5 to 11 years. First, the mode of administration and the format of the items of the questionnaire were modified in order to adapt them to the abilities of the children questioned. A French translation was also carried out. Second, the multidimensional model of the abbreviated version was tested using confirmatory analyses before examining the internal consistency, temporal stability, and convergent and divergent validities of this scale. Differential analyses were also carried out to highlight interindividual differences in terms of gender, age, and child group (children without disability vs. children with ID). According to the literature, girls should say they have a better life satisfaction in the school domain compared to boys (Kong, 2008); with increasing age, the peer relationships of children tend to develop more widely. New preoccupations with their self-esteem and their physical appearance also emerge (Harter, 1989). Thus, compared to the youngest children, older children should be more satisfied with their peer relationships and less satisfied in the "self" domain. Lastly, regardless of the degree of disability, every child with impairments sees their QOL and wellbeing decrease (Fattal \& Leblond, 2005). Consequently, children with ID should assess their overall life satisfaction and in the different domains of their life more negatively than children without disability, regardless of their age and gender.

\section{Method}

\section{Research design}

Data for this cross-sectional study was collected in 2014 and 2015 by trained graduate students. Only children without disability and children with mild/moderate ID aged 5 to 11 years who had been diagnosed by a paediatrician, a psychologist, and health professionals were included in the study.

\section{Ethical procedures}

Elementary school principals and primary caregivers of the participating children gave their written informed consent to the research team, and were assured that the data collected in the study would be kept confidential. The parents then received a letter explaining the study accompanied by a consent form. This was to be completed and signed by parents and the child to confirm their agreement. This research was conducted in accordance with the Code of Ethics of Psychologists (Groupe Interorganisationnel pour la Réglementation de la Déontologie des Psychologues, 2012).

\section{Participants}

Four hundred and eleven children aged from 5 to 11 years $(M=8.25$ years, $S D=1.707)$ participated in the study. They attended 15 French schools, half of them situated in an urban zone and the other half in a rural zone. The first group was composed of 340 children without disability (167 girls and 173 boys) attending the French equivalents of kindergarten to Grade 6 . Their mean age was 8.03 years $(S D=1.71)$. A second group constituted 71 children ( 29 girls and 42 boys) 
with mild/moderate ID $^{1}$ attending either a regular school in a regular class or Classe d'Inclusion Scolaire ${ }^{2}$ (CLIS 1) or a specialised institution. Their mean age was 9.25 years $(S D=1.284)$. Among these children, 53 had no associated disability (77.9\%), 14 had a physical disability associated with ID (20.4\%), and one child also had symptoms characteristic of autism spectrum disorder (1.7\%). Concerning age, there was a significant difference between the children without disability and the children with ID, $\chi^{2}(6,411)=41.163, p<.001$, and concerning the socioeconomic characteristics ${ }^{3}$ of their families; a more disadvantaged social origin was observed for families of children with ID, $\chi^{2}(2,355)=22.663, p<.001$. These different demographic characteristics are reported in Table 2.

\section{Measures}

The abbreviated form of the MSLSS was translated into French using a forward and backward translation procedure (Guillemin, Bombardier, \& Beaton, 1993). This scale was designed to assess the life satisfaction of children without disability and children with ID aged from 5 to 11 years. To do this, a multidimensional assessment was carried out to measure life satisfaction in general and in the specific domains of their life: family, school, friends, living environment, and self. The questionnaire includes 30 items formulated in affirmative sentences (see Appendix).

Table 2. Sociodemographic characteristics of the participants.

\begin{tabular}{|c|c|c|c|c|}
\hline \multirow{3}{*}{$\frac{\text { Variables }}{\text { Participants }}$} & \multirow{2}{*}{\multicolumn{2}{|c|}{$\begin{array}{l}\text { Number \% } \\
\text { Without ID }\end{array}$}} & \multirow{2}{*}{\multicolumn{2}{|c|}{$\begin{array}{c}\text { Number \% } \\
\text { ID }\end{array}$}} \\
\hline & & & & \\
\hline & 340 & 82.7 & 71 & 17.3 \\
\hline \multicolumn{5}{|l|}{ Gender } \\
\hline Girls & 167 & 49.1 & 29 & 40.8 \\
\hline Boys & 173 & 50.9 & 42 & 59.2 \\
\hline \multicolumn{5}{|l|}{ Age of the group } \\
\hline Less than 8 years & 136 & 40 & 22 & 31 \\
\hline More than 8 years & 204 & 60 & 49 & 69 \\
\hline \multicolumn{5}{|l|}{ Type of schooling } \\
\hline Kindergarten & 36 & 10.6 & 0 & 0 \\
\hline Grade 1 & 70 & 20.6 & 2 & 2.8 \\
\hline Grade 2 & 30 & 8.8 & 0 & 0 \\
\hline Grade 3 & 75 & 22.1 & 2 & 2.8 \\
\hline Grade 4 & 63 & 18.5 & 0 & 0 \\
\hline Grade 6 & 66 & 19.4 & 1 & 1.4 \\
\hline CLIS 1 & - & - & 41 & 57.8 \\
\hline Specialised institutions & - & - & 25 & 35.2 \\
\hline \multicolumn{5}{|l|}{ Disability associated with the ID ${ }^{a}$} \\
\hline None & - & - & 53 & 77.9 \\
\hline Physical disability & - & - & 14 & 20.4 \\
\hline Autism spectrum disorder & - & - & 1 & 1.7 \\
\hline \multicolumn{5}{|l|}{ Social background ${ }^{\mathrm{a}}$} \\
\hline Privileged & 105 & 36.3 & 5 & 7.6 \\
\hline Average & 133 & 46 & 39 & 59.1 \\
\hline Disadvantaged & 73 & 17.7 & 22 & 33.3 \\
\hline \multicolumn{5}{|l|}{ Marital status of the family ${ }^{a}$} \\
\hline Married, civil partnership & 230 & 73.5 & 53 & 75.7 \\
\hline Divorced, separated & 83 & 26.5 & 18 & 24.3 \\
\hline
\end{tabular}

Note. Without ID = without intellectual disability; ID = intellectual disability. ${ }^{\mathrm{a}}$ Some data are missing because some parents did not provide them.
By referring to recent weeks, the children had to assess their degree of satisfaction related to the different domains of their life. They had to choose from several responses the one that corresponded most to what they felt concerning each domain of their life. For each item, children had to assess their level of agreement on a continuum ranging from 1 (strongly disagree) to 6 (strongly agree).

The "child" and "parent" forms of the Positive and Negative Affect Schedule (PANAS) were also administered in their abbreviated form (Ebesutani et al., 2012) in order to check the convergent validity of the abbreviated form of the MSLSS. For each version, the PANAS assessed the positive and negative affectivity of children through 10 items. By referring to recent weeks, the child was asked how he or she felt in general. For each item, the notation was on a continuum ranging from 1 (not at all) to 5 (extremely). The two-factor structure of this scale was confirmed by confirmatory analyses for the PANAS child and parent forms. ${ }^{4}$

\section{Procedure}

For all children, three example items were given at the beginning of each questionnaire in order to familiarise them with the task.

For children older than 8 years $(n=204)$, the questionnaires were completed individually in class over about 45 minutes. For the very young children $(n=$ $136)$ and the children with ID $(n=71)$, the tests were carried out in a dual situation (experimenter/child) for about thirty minutes. The examiner read the items aloud and filled the questionnaires. This took place in a room isolated from the rest of the class for the children attending an ordinary school, or outside their life group in a "neutral" place (different from where they received their therapeutic care) for the children attending institutions or in a CLIS or a regular class. Visual supports adapted to each questionnaire were also designed to help the children choose their answers. ${ }^{5}$ For the MSLSS, the Likert-type scale with six degrees of agreement was represented by two distinct visual supports, each illustrating three answers. Each support represented three smiley faces in different colours of increasing size. The first illustrated the three degrees of agreement and the second presented the three degrees of disagreement. For the PANAS, the emotional frequency was represented in the same format by round shapes of increasing size coloured in darkening shades of green ranging from not at all to extremely. In addition, the children did a drawing in the middle of the MSLSS after the 15 th item so that they could renew their attention afterwards. 
Lastly, the temporal stability of the children's answers was tested for 150 children (25 with ID and 125 without disability) after a 2-week interval.

Regarding the validation of the scale, confirmatory structural analyses were performed using IBM SPSS AMOS software. To estimate the quality of fit of the model observed with the initial theoretical model, four indices were used: the model chi-square statistic, the comparative fit index (CFI), the Tucker-Lewis index (TLI), and the root mean square residual (RMSEA). Ideally, a good fit is reflected by a nonsignificant chi-square and CFI and TLI values of approximately 0.90 or higher (Byrne, 2001). For the RMSEA, a value of about 0.06 or lower was preferred for the model fit to be considered good (Hu \& Bentler, 1998). The internal consistency and test-retest reliability of the scale were also tested for each dimension of the questionnaire by computing Cronbach's alpha and correlation coefficients. For each of these indices, a value of 0.70 is generally considered sufficient to demonstrate internal consistency and temporal stability (Nunnally \& Bernstein, 1994). In addition, to test the divergent and convergent validity, the correlations between the abbreviated form of the MSLSS and both child positive and negative affectivity were analysed with regard to the criteria defined by Cohen (1992). A correlation is considered weak if its absolute value is

Table 3. Descriptive data per item of the abbreviated form of the MSLSS.

\begin{tabular}{|c|c|c|c|c|}
\hline & $M$ & SD & Skewness & Kurtosis \\
\hline Item 1 & 5 & 1.29 & -1.52 & 1.76 \\
\hline Item 2 & 5.09 & 1.20 & -1.54 & 1.99 \\
\hline Item 3 & 4.99 & 1.23 & -1.31 & 1.20 \\
\hline Item 4 & 5.46 & 1.01 & -2.25 & 5.11 \\
\hline Item 5 & 5.52 & 0.95 & -2.48 & 6.58 \\
\hline Item 6 & 4.95 & 1.34 & -1.29 & 0.83 \\
\hline Item 7 & 4.88 & 1.39 & -1.34 & 1.14 \\
\hline Item 8 & 5.02 & 1.36 & -1.47 & 1.45 \\
\hline Item 9 & 4.64 & 1.52 & -1.03 & 0.01 \\
\hline Item 10 & 5.31 & 1.21 & -2.05 & 3.58 \\
\hline Item 11 & 4.84 & 1.48 & -1.21 & 0.44 \\
\hline Item 12 & 4.72 & 1.53 & -1.12 & 0.15 \\
\hline Item 13 & 4.94 & 1.20 & -1.18 & 0.92 \\
\hline Item 14 & 5.59 & 0.82 & -2.50 & 7.12 \\
\hline Item 15 & 4.62 & 1.55 & -1.08 & 0.09 \\
\hline Item 16 & 4.88 & 1.52 & -1.40 & 0.92 \\
\hline Item 17 & 5.46 & 1.08 & -2.36 & 5.18 \\
\hline Item 18 & 4.98 & 1.39 & -1.51 & 1.53 \\
\hline Item 19 & 5.10 & 1.31 & -1.61 & 1.92 \\
\hline Item 20 & 4.96 & 1.35 & -1.45 & 1.44 \\
\hline Item 21 & 4.69 & 1.47 & -1.13 & 0.36 \\
\hline Item 22 & 5.18 & 1.27 & -1.73 & 2.33 \\
\hline Item 23 & 5.17 & 1.24 & -1.63 & 2.03 \\
\hline Item 24 & 4.90 & 1.55 & -1.37 & 0.74 \\
\hline Item 25 & 5.13 & 1.16 & -1.66 & 2.68 \\
\hline Item 26 & 5.36 & 1.17 & -2.16 & 4.46 \\
\hline Item 27 & 5.20 & 1.36 & -1.92 & 2.84 \\
\hline Item 28 & 4.46 & 1.77 & -0.86 & -0.67 \\
\hline Item 29 & 4.82 & 1.65 & -1.23 & 0.15 \\
\hline Item 30 & 5.18 & 1.37 & -1.74 & 2.03 \\
\hline
\end{tabular}

Note. MSLSS = Multidimensional Student's Life Satisfaction Scale. less than 0.30 , moderate if it lies between 0.30 and 0.50 , and strong if it is higher than 0.50. Finally, the effects of age, gender, family structure, and child group (children without disability vs. children with ID) on overall life satisfaction and in the different life domains of the children questioned were examined using multivariate analyses of variance.

\section{Results}

\section{Descriptive statistics}

The distributions of the scores obtained for the different items by all the children did not follow a normal distribution (see Table 3). As a result, a logarithmic transformation of these different variables was carried out in order to stabilise the variance and normalise the distributions presenting a positive skewness. After this recoding, the maximum likelihood procedure was applied to test the factorial structure of the scale and for all subsequent analyses (Tabachnick \& Fidell, 2012).

\section{Factorial structure}

In line with the initial model, a model with five firstorder factors corresponding to the five dimensions of life satisfaction and a second-order factor related to global life satisfaction was tested. The values obtained for the different fit indices in this first model suggested that it did not fit well the observed data. Thus, the residual variance matrices were examined in order to carry out the adjustments needed so that the model would fit the data well (Byrne, 2001). This analysis suggested adding covariances between the residual variances of Items 5 and 17, 15 and 22, 2 and 3, 7 and 10. It also highlighted a link between the latent variable "Friends" and the manifest variable of Item 2: "I am fun to be around." Regarding the conceptual similarities between these items or with the dimension "Friends" for Item 2, the modifications made to the model seemed consistent. When this second model was tested, all the items of the questionnaire had a saturation higher than 0.30 (see Table 4).

Moreover, the fit indices obtained were clearly better and showed that the model fitted the data collected to assess the life satisfaction of children: $\chi^{2}(395)=$ 705.340; $p<.001 ; \mathrm{CFI}=0.911 ; \mathrm{TLI}=0.902 ; \mathrm{RMSEA}=$ 0.044 (see Figure 1).

\section{Internal consistency and test-retest reliability}

Concerning the internal consistency for the whole scale, Cronbach's alpha was equal to 0.87 for the children 
Table 4. Factorial weights of the items of the abbreviated form of the MSLSS.

\begin{tabular}{|c|c|c|c|c|c|}
\hline & Factor 1 & Factor 2 & Factor 3 & Factor 4 & Factor 5 \\
\hline Item 1 & 0.70 & & & & \\
\hline Item 8 & 0.80 & & & & \\
\hline Item 9 & 0.62 & & & & \\
\hline Item 12 & 0.74 & & & & \\
\hline Item 22 & 0.67 & & & & \\
\hline Item 29 & 0.53 & & & & \\
\hline Item 4 & & 0.41 & & & \\
\hline Item 16 & & 0.75 & & & \\
\hline Item 18 & & 0.79 & & & \\
\hline Item 19 & & 0.78 & & & \\
\hline Item 20 & & 0.58 & & & \\
\hline Item 5 & & & 0.44 & & \\
\hline Item 6 & & & 0.50 & & \\
\hline Item 14 & & & 0.55 & & \\
\hline Item 15 & & & 0.54 & & \\
\hline Item 17 & & & 0.54 & & \\
\hline Item 21 & & & 0.54 & & \\
\hline Item 23 & & & 0.62 & & \\
\hline Item 11 & & & & 0.52 & \\
\hline Item 24 & & & & 0.65 & \\
\hline Item 27 & & & & 0.56 & \\
\hline Item 28 & & & & 0.40 & \\
\hline Item 30 & & & & 0.75 & \\
\hline Item 2 & & & & & 0.32 \\
\hline Item 3 & & & & & 0.39 \\
\hline Item 7 & & & & & 0.49 \\
\hline Item 10 & & & & & 0.55 \\
\hline Item 13 & & & & & 0.59 \\
\hline Item 25 & & & & & 0.66 \\
\hline Item 26 & & & & & 0.39 \\
\hline
\end{tabular}

Note. MSLSS = Multidimensional Student's Life Satisfaction Scale.

without disability and 0.88 for the children with ID. In addition, the coefficients obtained for the five dimensions of life satisfaction for all the children, distinguishing them according to their age bracket and their group of belonging, were all higher than or equal to 0.70 .
However, the results showed a moderate temporal stability calculated after a 2-week interval. Although the test-retest reliability coefficients were all significant, they were less than the threshold of 0.70 for all the dimensions of life satisfaction of the children without disability. Nevertheless, a better temporal stability was found for the children with ID, with only two dimensions whose correlation coefficients were lower than 0.70. These various results are presented in Table 5.

\section{Convergent and discriminant validities}

First, for the assessment carried out by both the children without disability and the children with ID, their positive and negative affectivity scores were significantly correlated with overall life satisfaction and in the different life domains. The negative affectivity scores obtained with the PANAS child form seemed significantly and negatively correlated with life satisfaction for all the dimensions. The correlations were weak to moderate $(0.18-0.40)$. These results were lower than the correlations obtained between the positive affectivity measured by the children and their life satisfaction (0.23-0.60). However, the correlations appeared nonsignificant for almost all the dimensions of the life satisfaction of children, whether it was the positive or negative affectivity assessed by the parents of children without disability or those with ID (see Table 6).

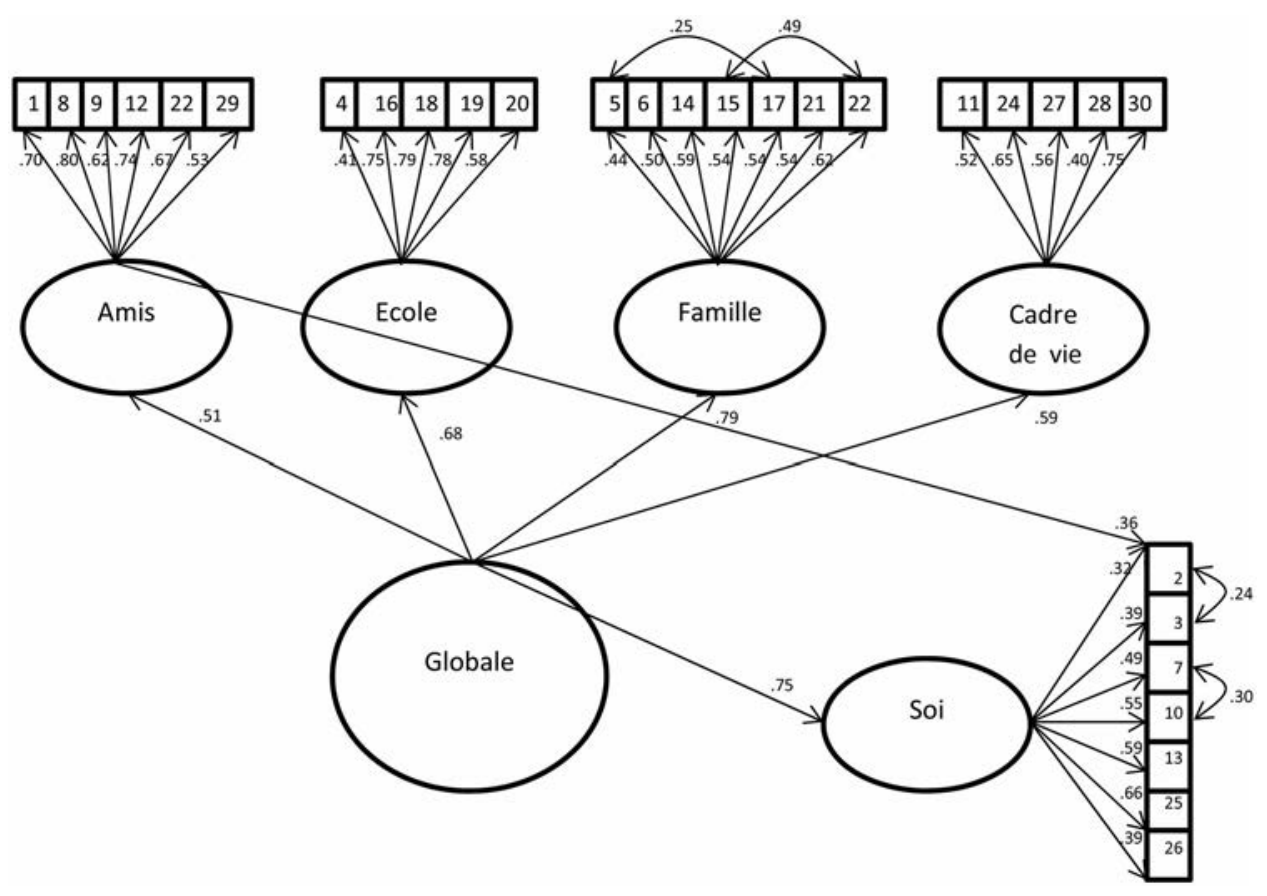

Figure 1. Confirmatory structural analysis diagram of the abbreviated form of the MSLSS. 
Table 5. Coefficients of internal consistency and test-retest reliability of the abbreviated form of the MSLSS.

\begin{tabular}{lcccccc}
\hline & \multicolumn{2}{c}{ Cronbach's $a$} & & \multicolumn{2}{c}{ Correlation coefficients } \\
\cline { 2 - 3 } & $\begin{array}{c}\text { Without ID } \\
\text { All }\end{array}$ & $\begin{array}{c}\text { Without ID } \\
<8 \text { years }\end{array}$ & ID & & $\begin{array}{c}\text { Without ID } \\
\text { All }\end{array}$ & $\begin{array}{c}\text { Without ID } \\
<8 \text { years }\end{array}$ \\
\hline Friends & 0.83 & 0.79 & 0.76 & $0.60^{* *}$ & $0.58^{* *}$ \\
School & 0.77 & 0.70 & 0.87 & $0.50^{* *}$ & $0.48^{* *}$ & $0.77^{* *}$ \\
Family & 0.76 & 0.73 & 0.70 & $0.56^{* *}$ & $0.71^{* *}$ \\
Environment & 0.71 & 0.70 & 0.70 & $0.48^{* *}$ & $0.51^{* *}$ \\
Self & 0.72 & 0.70 & 0.71 & $0.48^{* *}$ & $0.46^{* *}$ & $0.60^{* *}$ \\
Overall & 0.87 & 0.84 & 0.88 & $0.69^{* *}$ & $0.69^{* *}$ & $0.82^{* *}$ \\
\hline
\end{tabular}

Note. MSLSS = Multidimensional Student's Life Satisfaction Scale.

${ }^{* *} p<.01$.

Table 6. Relationships between the abbreviated form of the MSLSS and the PANAS child and parent forms.

\begin{tabular}{|c|c|c|c|c|c|c|c|c|}
\hline & \multicolumn{8}{|c|}{ Correlation coefficients } \\
\hline & \multicolumn{4}{|c|}{ PANAS-C (Child) } & \multicolumn{4}{|c|}{ PANAS-CP (Parent) } \\
\hline & \multicolumn{2}{|c|}{$\begin{array}{l}\text { Positive } \\
\text { affectivity }\end{array}$} & \multicolumn{2}{|c|}{$\begin{array}{l}\text { Negative } \\
\text { affectivity }\end{array}$} & \multicolumn{2}{|c|}{$\begin{array}{l}\text { Positive } \\
\text { affectivity }\end{array}$} & \multicolumn{2}{|c|}{$\begin{array}{l}\text { Negative } \\
\text { affectivity }\end{array}$} \\
\hline & Without ID ${ }^{\mathrm{a}}$ & $I D^{b}$ & Without ID ${ }^{a}$ & $I D^{b}$ & Without ID ${ }^{\mathrm{a}}$ & $I D^{b}$ & Without ID ${ }^{a}$ & $I D^{b}$ \\
\hline School & $0.35^{* *}$ & $0.54^{* *}$ & $-0.21^{* *}$ & $-0.22^{* *}$ & 0.06 & 0.13 & 0.02 & -0.18 \\
\hline Friends & $0.23^{* *}$ & $0.35^{* *}$ & $-0.25^{* *}$ & $-0.40^{* *}$ & 0.03 & 0.01 & 0.09 & -0.15 \\
\hline Family & $0.30^{* *}$ & $0.30^{* *}$ & $-0.19^{* *}$ & $-0.27^{* *}$ & $0.13^{*}$ & -0.02 & -0.20 & -0.19 \\
\hline Environment & $0.25^{* *}$ & $0.45^{* *}$ & $-0.18^{*}$ & -0.10 & 0.04 & 0.01 & -0.01 & -0.08 \\
\hline Self & $0.41^{* *}$ & $0.53^{* *}$ & $-0.18^{* *}$ & $-0.28^{* *}$ & 0.11 & -0.13 & 0.01 & 0.06 \\
\hline Overall & $0.43^{* *}$ & $0.60^{* *}$ & $-0.30^{* *}$ & $-0.25^{* *}$ & 0.103 & 0.02 & 0.03 & -0.16 \\
\hline
\end{tabular}

Note. MSLSS = Multidimensional Student's Life Satisfaction Scale; PANAS = Positive and Negative Affect Schedule.

${ }^{\mathrm{a}} n=340$.

$\mathrm{b}_{n}=71$.

${ }^{*} p<.05$.

${ }^{* *} p<.01$.

\section{Differential analyses}

First, the analyses revealed a main effect of gender on the dimension "School," $F(1,409)=9.225, p<.010, \eta^{2}=$ 0.022. On average, girls reported higher school satisfaction $(M=5.24, S D=0.072)$ compared to boys $(M=$ 4.94, $S D=0.069)$. In addition, a significant effect of child appeared for the "Friends," $F(1,409)=4.450$, $p<.050, \eta^{2}=0.011$, and "Self," $F(1,409)=16.321$, $p<.001, \eta^{2}=0.038$, dimensions. The children younger than 8 years described themselves as more satisfied in the Self domain $(M=5.27, S D=0.060)$ compared to those older than 8 years $(M=5.01, S D=0.049)$. In contrast, the latter tended to describe themselves as more satisfied with their peer relationships $(M=4.98, S D=$ $0.071)$ compared to younger children $(M=4.74, S D=$ 0.086). Furthermore, the results revealed no effect of family structure on the different dimensions of children's life satisfaction (see Table 7).

On the other hand, after controlling for the effects of gender, social background, and the age of children, differences in QOL scores between children without disability and children with ID were observed in four domains of life satisfaction: School, $F(1,350)=4.285, p<.010, \eta^{2}=$ 0.012 , Friends, $F(1,350)=27.411, p<.001, \eta^{2}=0.092$, Family, $F(1,350)=9.840, p<.050, \eta^{2}=0.036$, and overall life satisfaction, $F(1,340)=12.401, p<.010, \eta^{2}=0.039$.
Overall, the children with ID thus appeared less satisfied with their life $(M=4.770, S D=0.079)$ than children without disability $(M=5.081, S D=0.037)$. Moreover, they described their relationships with their peers $(M=4.290, S D=0.16)$ and their family $(M=4.851$, $S D=0.098)$ more negatively compared to children without disability (Friends: $M=5.027, S D=0.059$; Family: $M=5.195, S D=0.046)$. Children with ID also reported higher school satisfaction $(M=4.826, S D=0.128)$ than children without disability $(M=5.12, S D=0.059)$. Finally, the analyses revealed an interaction effect between child age and child group for the dimension Self, $F(1,355)=7.331, p<.010, \eta^{2}=0.021$. Although the children without disability said they were more satisfied in the Self domain before 8 years old $(M=5.34$, $S D=0.064$ ), conversely, with increasing age the children with ID reported a higher satisfaction with themselves (under 8 years old: $M=4.829, S D=0.156$; over 8 years old: $M=5.048, S D=0.108$; see Table 8 ).

\section{Discussion}

Consistent with the results obtained with the original version of the MSLSS, the confirmatory analyses conducted in this study confirmed its multifactorial structure with five first-order factors and one second-order 
Table 7. Effects of gender, age, and family structure on all the dimensions of the life satisfaction of children.

\begin{tabular}{lcccc}
\hline & $d f$ & $F$ & $p$ & Partial eta $^{2}$ \\
\hline School & & & & \\
Gender & $(1,409)$ & 9.225 & 0.003 & 0.022 \\
Age & $(1,409)$ & 1.125 & 0.289 & 0.003 \\
Family structure & $(1,381)$ & 0.368 & 0.545 & 0.001 \\
Age $\times$ Gender & $(1,353)$ & 2.170 & 0.142 & 0.007 \\
Age $\times$ Family structure & $(1,353)$ & 0.004 & 0.949 & 0.001 \\
$\quad$ Gender $\times$ Family structure & $(2,353)$ & 0.155 & 0.857 & 0.001 \\
Family & & & & \\
Gender & $(1,409)$ & 0.968 & 0.326 & 0.002 \\
Age & $(1,409)$ & 2.483 & 0.116 & 0.006 \\
Family structure & $(1,381)$ & 0.277 & 0.599 & 0.001 \\
Age $\times$ Gender & $(1,353)$ & 2.097 & 0.147 & 0.006 \\
Age $\times$ Family structure & $(1,353)$ & 0.098 & 0.148 & 0.006 \\
Gender $\times$ Family structure & $(2,353)$ & 0.413 & 0.662 & 0.003 \\
Friends & & & & \\
Gender & $(1,409)$ & 0.001 & 0.971 & 0.000 \\
Age & $(1,409)$ & 4.450 & 0.036 & 0.011 \\
Family structure & $(1,381)$ & 0.393 & 0.531 & 0.001 \\
Age $\times$ Gender & $(1,353)$ & 0.472 & 0.512 & 0.001 \\
Age $\times$ Family structure & $(1,353)$ & 0.075 & 0.785 & 0.001 \\
Gender $\times$ Family structure & $(2,353)$ & 0.413 & 0.662 & 0.003 \\
Living environment & & & & \\
Gender & $(1,409)$ & 0.211 & 0.646 & 0.001 \\
Age & $(1,409)$ & 1.501 & 0.220 & 0.004 \\
Family structure & $(1,381)$ & 2.485 & 0.116 & 0.006 \\
Age $\times$ Gender & $(1,353)$ & 0.028 & 0.867 & 0.001 \\
Age $\times$ Family structure & $(1,353)$ & 0.030 & 0.863 & 0.001 \\
$\quad$ Gender $\times$ Family structure & $(2,353)$ & 0.432 & 0.650 & 0.003 \\
Self & & & & \\
Gender & $(1,409)$ & 2.017 & 0.156 & 0.005 \\
Age & $(1,409)$ & 16.32 & 0.001 & 0.038 \\
Family structure & $(1,381)$ & 1.461 & 0.227 & 0.004 \\
Age $\times$ Gender & $(1,353)$ & 1.724 & 0.190 & 0.005 \\
Age $\times$ Family structure & $(1,353)$ & 1.674 & 0.197 & 0.005 \\
Gender $\times$ Family structure & $(2,353)$ & 0.062 & 0.940 & 0.001 \\
Overall life satisfaction & & & & \\
Gender & $(1,409)$ & 2.776 & 0.096 & 0.007 \\
Age & $(1,409)$ & 0.321 & 0.571 & 0.001 \\
Family structure & $(1,381)$ & 0.867 & 0.352 & 0.002 \\
Age $\times$ Gender & $(1,353)$ & 2.763 & 0.097 & 0.008 \\
Age $\times$ Family structure & $(1,353)$ & 0.226 & 0.635 & 0.001 \\
Gender $\times$ Family structure & $(2,353)$ & 0.180 & 0.832 & 0.001 \\
\hline & & & & \\
\hline
\end{tabular}

factor. In comparison with the original form of Huebner et al. (2012), only one modification was made to the model: A link was added between the latent variable Friends and the manifest variable corresponding to Item 2 ("I am fun to be around"). Very good levels of internal consistency were obtained for both children with and without ID. The values obtained for the five dimensions of life satisfaction for all the children, distinguishing them according to age and ID, were all higher than or equal to 0.70 (from 0.70 to 0.88 ). These coefficients are similar to those reported for the original version, with coefficients ranging from 0.71 (Self) to 0.91 (Family; Huebner et al., 2012). However, the test-retest coefficients calculated after a 2-week interval highlighted a moderate to weak temporal stability, which seemed more pronounced in children with ID. The test-retest reliability was not assessed in the validation study of the abbreviated form of the MSLSS (Huebner et al., 2012). Nonetheless, Diener (2009) underlined the
Table 8. Effect of child group (children without disability vs children with ID) on the dimensions of the abbreviated form of the MSLSS after controlling for effects of gender, age, and social background.

\begin{tabular}{lcccc}
\hline & $d f$ & $F$ & $p$ & Partial eta $^{2}$ \\
\hline School & & & & \\
$\quad$ Group & $(1,350)$ & 4.285 & 0.007 & 0.012 \\
Group $\times$ Age & $(1,350)$ & 0.815 & 0.367 & 0.002 \\
$\quad$ Group $\times$ Gender & $(1,350)$ & 0.141 & 0.708 & 0.001 \\
$\quad$ Group $\times$ Social background & $(1,350)$ & 1.821 & 0.163 & 0.011 \\
Family & & & & \\
$\quad$ Group & $(1,350)$ & 9.840 & 0.011 & 0.036 \\
$\quad$ Group $\times$ Age & $(1,350)$ & 0.118 & 0.732 & 0.001 \\
$\quad$ Group $\times$ Gender & $(1,350)$ & 2.120 & 0.146 & 0.001 \\
$\quad$ Group $\times$ Social background & $(1,350)$ & 0.325 & 0.723 & 0.002 \\
Friends & & & & \\
$\quad$ Group & $(1,350)$ & 27.411 & 0.001 & 0.092 \\
$\quad$ Group $\times$ Age & $(1,350)$ & 0.244 & 0.621 & 0.001 \\
$\quad$ Group $\times$ Gender & $(1,350)$ & 0.234 & 0.629 & 0.001 \\
$\quad$ Group $\times$ Social background & $(1,350)$ & 0.417 & 0.659 & 0.003 \\
Living environment & & & & \\
$\quad$ Group & $(1,350)$ & 0.051 & 0.936 & 0.002 \\
$\quad$ Group $\times$ Age & $(1,350)$ & 0.686 & 0.408 & 0.002 \\
$\quad$ Group $\times$ Gender & $(1,350)$ & 1.022 & 0.313 & 0.003 \\
$\quad$ Group $\times$ Social background & $(1,350)$ & 0.315 & 0.730 & 0.002 \\
Self & & & & \\
$\quad$ Group & $(1,350)$ & 2.089 & 0.004 & 0.042 \\
$\quad$ Group $\times$ Age & $(1,350)$ & 7.331 & 0.007 & 0.021 \\
$\quad$ Group $\times$ Gender & $(1,350)$ & 0.005 & 9.42 & 0.001 \\
$\quad$ Group $\times$ Social background & $(1,350)$ & 0.024 & 0.536 & 0.004 \\
Overall life satisfaction & & & & \\
$\quad$ Group & $(1,350)$ & 12.401 & 0.008 & 0.039 \\
Group $\times$ Age & $(1,350)$ & 0.342 & 0.349 & 0.003 \\
$\quad$ Group $\times$ Gender & $(1,350)$ & 0.002 & 0.961 & 0.001 \\
$\quad$ Group $\times$ Social background & $(1,350)$ & 0.892 & 0.411 & 0.005 \\
\hline Note. ID $=$ intellectual disability; MSLSS Multidimensional Student's Life Sat- \\
isfaction Scale. & & & & \\
& & & &
\end{tabular}

temporal variability found with scales assessing subjective wellbeing. Unlike objective assessments, these instruments are more sensitive to the events experienced by the people questioned. These results may also be explained by the effect of age and ID on the reliability and reproducibility of children's responses. Various authors emphasise that self-report scales might introduce some bias in the responses of very young children or children with ID (Rodary et al., 2001) due to a tendency to acquiescence, social desirability, and difficulties in assessing the subjective aspects of their life (Fattal \& Leblond, 2005; Hodgkinson, d'Anjou, Dazord, \& Berard, 2002; Martin-Laval, 1992). Young children (before the age of 8 years) and children with ID may have problems understanding and interpreting the questions because of their language as well as their general cognitive ability (Ravens-Sieberer et al., 2006). In addition, some research shows that young children (Chambers \& Johnston, 2002) and children with ID (Hartley \& MacLean, 2006) may have difficulty in answering questions using Likert scales. The latter have a tendency to choose the most positive alternative in this response format, which requires the complex task of distinguishing subtle differences in responses (Chambers \& Johnston, 2002; Hartley \& 
MacLean, 2006). To correct this bias, authors suggest reducing the Likert scale to 5 points maximum (Hartley \& MacLean, 2006). The use of pictorial representations can also help children distinguish the response degrees (Zabalia \& Corfec, 2008). In this study, we chose to keep the 6-point Likert scale format of the original version of the MSLSS to avoid reducing the sensitivity of the instrument. However, these were represented by two distinct visual supports each illustrating three response choices. Each support represented three smiley faces in different colours and of increasing size. Despite these adaptations, children may have had difficulties in differentiating the smiley faces. Changes in colour and size may have functioned as confounding variables.

On the other hand, the correlation coefficients calculated between the scores of affectivity and the life satisfaction of children confirmed the convergent and discriminant validities of this scale. The significant relationships revealed between self-assessment of affectivity and all the dimensions of life satisfaction confirm the results previously obtained with adults and children aged over 11 years (Diener, 2012). These results suggest that the positive and negative affects felt by very young children or children with ID also contribute to their QOL and their subjective wellbeing (Diener, 2012). However, compared to the relationship between positive affectivity assessed by the children and their life satisfaction, a weaker link was observed between negative affectivity and life satisfaction. These results confirm those of Huebner and Dew (1996), who found a weaker relationship between global life satisfaction and negative affectivity $(r=-0.27)$ than positive affectivity $(r=0.43)$. Moreover, the absence of a link between the affectivity of children assessed by their parents and all the dimensions of their life satisfaction confirms the poor agreement between the assessments made by members of the child's family and by the children themselves. In fact, the appreciation of the QOL and wellbeing of children by intermediary assessors seems more faithful to the feelings of children concerning objective aspects than subjective aspects (Eiser \& Morse, 2001).

The results of multivariate analyses also showed that the different dimensions of life satisfaction assessed with this scale discriminate quite clearly between the children. First, in accordance with the international literature, girls described themselves as more satisfied in the school domain than boys (Kong, 2008). On the other hand, the children over 8 years old assessed their life satisfaction in the domain of Self more negatively than the younger children, but they said they were more satisfied with their peer relationships. These results may be explained from a developmental perspective as, with increasing age, physical, emotional, social, and cognitive developments have repercussions on the different domains of children's lives. New preoccupations linked with physical appearance, social skills, and selfperception emerge (Harter, 1989). As a result, many authors note a decline in children's self-esteem (Deihl, Vicary, \& Deike, 1997), which is strongly and positively correlated with the level of their life satisfaction (Huebner \& Dew, 1996). In parallel, their friendships develop and evolve into new reciprocal friendships created via a trusting relationship (Poulin \& Chan, 2010). These new connections lead to feelings of safety, which predict an increase in wellbeing and positive moods (Berndt, 2002). However, these results must be interpreted with caution. One factor that may explain the differences observed between typically developing children and children with ID is the type of schooling, which differed considerably across groups (regular school vs. CLIS 1 vs. specialised institutions). The context of schooling may have an impact on life satisfaction (Proctor, Linley, \& Maltby, 2009). Thus, the validity of the comparison between children with and without ID appears to be limited.

Lastly, an effect of child group on the life satisfaction of children was observed. Compared to children without disability, the children with ID described themselves as less satisfied with their life in general as well as in the school, family, and friends domains. Regardless of the degree of impairment, all children with disability see their wellbeing diminished (Cousson-Gélie, 2013; Fattal \& Leblond, 2005). The majority of works underline the isolation of children with disability and their social exclusion, which are the consequences of significant stigmatisation by their peers without disability (Nadeau \& Tessier, 2003). Moreover, changes impact the professional practice of parents (often only one parent works in the couple), the rhythm of family life, and relationships with siblings, thus altering family relationships (Dobson, Middleton, \& Beardsworth, 2001; Lopez, Clifford, Minnes, \& Ouellette-Kuntz, 2008). Educational failure in these young people arouses feelings of personal inadequacy associated with the school domain (Ninot, Bilard, Delignières, \& Sokolowski, 2000).

Finally, the preliminary results of this study show that our adaptation of the MSLSS presents satisfactory psychometric qualities. However, several limitations must be considered and further research is needed to ensure confidence in the use of this scale with younger children and children with ID living in France. First, due to the limited cognitive and language abilities of children with ID, it would be relevant to test the structural invariance of this scale according to child group. Our sample of children with ID was too small to carry out multigroup analyses and to determine whether the structure of the 
questionnaire, the factorial weights, and the residual variances of the items can be considered invariant. Thus, following the procedure proposed by Byrne (2004), a larger sample of children with ID would allow us to test the structural invariance of the scale and to determine whether Huebner's model of QOL applies equally to children with and without ID. The hypothesis according to which the QOL of children with ID is composed of the same dimensions as children without disability (Magerotte, 2013; Schalock, 1993) could also be tested. Moreover, the temporal stability of the questionnaire is moderate. This could be explained by the fact that the younger children and children with ID had difficulties understanding the wording of some items and discriminating multiple response choices. As part of our future research, the wording of some items could be simplified to facilitate administration to children with ID. For example, Lunsky, Emery, and Benson (2002) suggest incorporating paraphrases and/or definitions of terms in the questionnaire. Other authors note that scenarios with dolls, puppets, and cuddly toys can be used to explain the items of questionnaires (Eiser, Cotter, Oades, Seamark, \& Smith, 1999). To help children discriminate better the degrees of agreement, the representation of smiley faces could be modified. In fact, each visual support should represent smiley faces in a different colour gradient. For example, smiley faces corresponding to degrees of agreement could be represented by a gradation of green, whereas smiley faces referring to degrees of disagreement could appear in a red gradient. This new revised and simplified life satisfaction scale could then be tested with children with moderate to severe ID. Lastly, the predictive validity of the scale should be evaluated in a longitudinal study and the subscales should be validated. Self-esteem is recognised as a key determinant of QOL and mental health (Brown, 1998). Thus, it would be appropriate to study the relationships between the different dimensions of QOL and self-esteem of children.

In conclusion, despite these limitations, our adaptation of the abbreviated form of the MSLSS is the first self-assessment QOL instrument suitable for children as young as 5 years old and children with ID to be the subject of a validation study in a French-speaking population. This scale is of major interest for childhood professionals. It will enable them to assess the perception that children have of their wellbeing in important domains of their life, to take into account the specific needs of these children, and to promote their wellbeing. In addition, this scale provides researchers in psychology with the opportunity to enrich their knowledge on the wellbeing of children with ID and to respond to political and governmental legislation related to the United
Nations Convention on the Rights of the Child (United Nations, 1989), and the recommendations of the OCDE (2009), which give a particular impetus to awareness and improvement of the wellbeing of children.

\section{Notes}

1. According to the fifth edition of the Diagnostic and Statistical Manual of Mental Disorders (DSM-5; American Psychiatric Association, 2013), ID is a disorder with onset during the developmental period that includes both intellectual and adaptive functioning deficits in conceptual, social, and practical domains.

2. CLIS 1 are classes for children aged 7 to 12 years with significant problems in cognitive functions. They enable pupils with disability to follow a curriculum in an ordinary school in a specialised class of no more than 12 children. The appropriate physical adaptations and teaching materials are provided according to the age, disability, and capacities of each child.

3. Social categories determined according to the grid used in surveys by the French Direction de l'Evaluation de la Prospective et de la Performance (DEPP; Evaluation, Forecasting and Performance Department) of the Ministry of National Education, based on the socio-professional category of the reference person of the family or the father.

4. The fit of the model for the data collected with the child form were: $\chi^{2}(33)=66.34, p<.001 ; \quad$ RMSEA $=0.050$; $\mathrm{CFI}=0.939$; $\mathrm{TLI}=0.917$; internal consistency: positive affectivity $=0.57$ and negative affectivity $=0.65$; and the parent form, $\chi^{2}(31)=66.68, p<.001$; RMSEA $=$ 0.056; $\mathrm{CFI}=0.946$; $\mathrm{TLI}=0.927$; internal consistency: positive affectivity $=0.71$ and negative affectivity $=0.66$.

5. Visual supports are available upon request by contacting the first author.

\section{Disclosure statement}

No potential conflict of interest was reported by the authors.

\section{References}

American Psychiatric Association. (2013). Diagnostic and statistical manual of mental disorders (5th ed.). Arlington, VA: American Psychiatric Publishing.

Berndt, T. J. (2002). Friendship quality and social development. Current Directions in Psychological Science, 11, 710. doi:10.1111/1467-8721.00157

Brown, J. D. (1998). The self. Boston, MA: McGraw-Hill.

Bruchon-Schweitzer, M. (2002). Psychologie de la santé: Modèles, concepts et méthodes [Health psychology: Models, concepts and methods]. Paris, France: Dunod.

Byrne, B. M. (2001). Structural equation modeling with AMOS: Basic concepts, applications, and programming. Mahwah, NJ: Erlbaum.

Byrne, B. M. (2004). Testing for multigroup invariance using AMOS graphics: A road less traveled. Structural Equation Modeling: A Multidisciplinary Journal, 11, 272-300. doi:10.1207/s15328007sem1102_8 
Chambers, C. T., \& Johnston, C. (2002). Developmental differences in children's use of rating scales. Journal of Pediatric Psychology, 27, 27-36. doi:10.1093/jpepsy/27.1.27

Cohen, J. (1992). A power primer. Psychological Bulletin, 112, 155-159. doi:10.1037/0033-2909.112.1.155

Coudronnière, C., Bacro, F., Guimard, G., \& Florin, A. (2015). Quelle conception de la qualité de vie et du bien-être chez des enfants de 5 à 11 ans? [What is the conception of quality of life and well-being among children aged 5 to 11 years old?]. Enfance, 2015, 225-243. doi:10.4074/S0013754515002049

Cousson-Gélie, F. (2013). Les déterminants psychosociaux de la qualité de vie chez des patients atteints de maladie grave et/ou chronique [Psychosocial determinants of quality of life in patients with severe and/or chronic disease]. In F. Bacro (Ed.), La qualité de vie: Approches psychologiques (pp. 103-115). Rennes, France: Presses universitaires de Rennes.

Deihl, L. M., Vicary, J. R., \& Deike, R. C. (1997). Longitudinal trajectories of self-esteem from early to middle adolescence and related psychosocial variables among rural adolescents. Journal of Research on Adolescence, 7, 393-411. doi:10.1207/ s15327795jra0704_3

Diener, E. (1984). Subjective well-being. Psychological Bulletin, 95, 542-575.

Diener, E. (Ed.). (2009). Assessing well-being: The collected works of Ed Diener. New York, NY: Springer. doi:10.1007/ 978-90-481-2354-4

Diener, E. (2012). New findings and future directions for subjective well-being research. American Psychologist, 67, 590597. doi:10.1037/a0029541

Diener, E., Lucas, R. E., \& Oishi, S. (2002). Subjective wellbeing: The science of happiness and life satisfaction. In C. R. Snyder, \& S. J. Lopez (Eds.), The handbook of positive psychology (pp. 63-73). New York, NY: Oxford University Press.

Dobson, B., Middleton, S., \& Beardsworth, A. (2001). The impact of childhood disability on family life. Layerthorpe, UK: Joseph Rowntree Foundation.

Ebesutani, C., Regan, J., Smith, A., Reise, S., Higa-McMillan, C., \& Chorpita, B. F. (2012). The 10-item Positive and Negative Affect Schedule for Children, child and parent shortened versions: Application of item response theory for more efficient assessment. Journal of Psychopathology and Behavioral Assessment, 34, 191-203. doi:10.1007/ s10862-011-9273-2

Eiser, C., Cotter, I., Oades, P., Seamark, D., \& Smith, R. (1999). Health-related quality-of-life measures for children. International Journal of Cancer, 83(S12), 87-90. doi:10. 1002/(SICI)1097-0215(1999)83:12+<87::AID-IJC16>3.0. $\mathrm{CO} ; 2-\mathrm{O}$

Eiser, C., \& Morse, R. (2001). A review of measures of quality of life for children with chronic illness. Archives of Disease in Childhood, 84, 205-211. doi:10.1136/adc.84.3.205

Fattal, C., \& Leblond, C. (2005). Évaluation des aptitudes fonctionnelles, du handicap et de la qualité de vie chez le blessé médullaire. [Assessment of functional abilities, handicap and quality of life in patients with spinal cord injuries]. Annales de Réadaptation et de Médecine Physique, 48, 346-360. doi:10.1016/j.annrmp.2005.03.006

Funk, B. A., III, Huebner, E. S., \& Valois, R. F. (2006). Reliability and validity of a brief life satisfaction scale with a high school sample. Journal of Happiness Studies, 7, 4154. doi:10.1007/s10902-005-0869-7
Gilman, R., Huebner, E. S., \& Laughlin, J. E. (2000). A first study of the Multidimensional Students' Life Satisfaction Scale with adolescents. Social Indicators Research, 52, 135160. doi:10.1023/A:1007059227507

Groupe Interorganisationnel pour la Réglementation de la Déontologie des Psychologues. (2012). Actualisation du Code de déontologie des psychologues de mars 1996. Février 2012 [Updating of the Code of Ethics for Psychologists of March 1996. February 2002]. Retrieved from http://www. codededeontologiedespsychologues.fr/IMG/pdf

Guillemin, F., Bombardier, C., \& Beaton, D. (1993). Cross-cultural adaptation of health-related quality of life measures: Literature review and proposed guidelines. Journal of Clinical Epidemiology, 46, 1417-1432. doi:10.1016/08954356(93)90142-N

Harter, S. (1989). Causes, correlates and the functional role of global self-worth: A life-span perspective. In J. Kollignan, \& R. Sternberg (Eds.), Perceptions of competence and incompetence across the life span (pp. 67-97). New York, NY: Springer-Verlag.

Hartley, S. L., \& MacLean, W. E., Jr. (2006). A review of the reliability and validity of Likert-type scales for people with intellectual disability. Journal of Intellectual Disability Research, 50, 813-827. doi:10.1111/j.1365-2788.2006. 00844.x

Hodgkinson, I., d'Anjou, M. C., Dazord, A., \& Berard, C. (2002). Qualité de vie d'une population de 54 enfants infirmes moteurs cérébraux marchants. Étude transversale [Quality of life of a population of 54 ambulatory children with cerebral palsy. A cross-sectional study]. Annales de Réadaptation et de Médecine Physique, 45, 154-158. doi:10.1016/S0168-6054(02)00195-2

Hu, L., \& Bentler, P. M. (1998). Fit indices in covariance structure modeling: Sensitivity to underparameterized model misspecification. Psychological Methods, 3, 424-453. doi:10.1037/1082-989X.3.4.424

Huebner, E. S. (1994). Preliminary development and validation of a multidimensional life satisfaction scale for children. Psychological Assessment, 6, 149-158. doi:10.1037/ 1040-3590.6.2.149

Huebner, E. S., \& Dew, T. (1996). The interrelationships of positive affect, negative affect and life satisfaction in an adolescent sample. Social Indicators Research, 38, 129-137. doi:10.1007/BF00300455

Huebner, E. S., Zullig, K. J., \& Saha, R. (2012). Factor structure and reliability of an abbreviated version of the Multidimensional Students' Life Satisfaction Scale. Child Indicators Research, 5, 651-657. doi:10.1007/s12187-0129140-z

Kong, C.-K. (2008). Classroom learning experiences and students' perceptions of quality of school life. Learning Environments Research, 11, 111-129. doi:10.1007/s10984008-9040-9

Lemétayer, F., \& Gueffier, M. (2006). Evaluation de la qualité de vie des enfants et des adolescents avec une déficience intellectuelle pris en charge dans un institut spécialisé [Evaluation of the quality of life of children and adolescents with intellectual disability cared for in a specialised institute]. Revue Francophone de la Déficience Intellectuelle, 17, 65-77. Retrieved from http://www.rfdi.org/wp-content/ uploads/2013/05/LEMETAYER_v17.pdf 
Lopez, V., Clifford, T., Minnes, P., \& Ouellette-Kuntz, H. (2008). Parental stress and coping in families of children with and without developmental delays. Journal on Developmental Disabilities, 14, 100-104.

Lunsky, Y., Emery, C. F., \& Benson, B. A. (2002). Staff and selfreports of health behaviours, somatic complaints, and medications among adults with mild intellectual disability. Journal of Intellectual \& Developmental Disability, 27, 125-135. doi:10.1080/13668250220135079-4

Magerotte, G. (2013). Qualité de vie des personnes ayant un handicap: Pratiques d'évaluation et d'intervention en autisme et/ou déficience intellectuelle [Quality of life for people with disability: Assessment practices and intervention in autism and/or intellectual disability]. In F. Bacro (Ed.), La qualité de vie: Approches psychologiques (pp. 85-102). Rennes, France: Presses universitaires de Rennes.

Manificat, S., Dazord, A., Cochat, P., \& Nicolas, J. (1997). Évaluation de la qualité de vie en pédiatrie: Comment recueillir le point de vue de l'enfant. [Assessment of quality of life in pediatrics: A questionnaire to assess the child's own opinion]. Archives de Pédiatrie, 4, 1238-1246. doi:10.1016/ S0929-693X(97)82616-4

Martin-Laval, H. (1992). Évaluation de la qualité de vie des personnes présentant une déficience intellectuelle [Evaluation of quality of life of adults with intellectual disability]. Revue Francophone de la Déficience Intellectuelle, 3, 139-141. Retrieved from http://www.rfdi.org/wpcontent/uploads/2013/06/MARTIN-LAVAL_v3sp.pdf

Matza, L. S., Swensen, A. R., Flood, E. M., Secnik, K., \& Leidy, N. K. (2004). Assessment of health-related quality of life in children: A review of conceptual, methodological, and regulatory issues. Value in Health, 7, 79-92. doi:10.1111/j.15244733.2004.71273.x

Nadeau, L., \& Tessier, R. (2003). Relations sociales entre enfants à l'âge scolaire: Effet de la prématurité et de la déficience motrice [Social relationships between schoolchildren: The effect of prematurity and motor deficiency]. Enfance, 55, 48-55. doi:10.3917/enf.551.0048

Ninot, G., Bilard, D., Delignières, D., \& Sokolowski, M. (2000). La survalorisation du sentiment de compétence de l'adolescent déficient intellectuel en milieu spécialisé [Overestimation of perceived competence in adolescents placed in specialised schools]. Revue Européenne de Psychologie Appliquée, 50, 165-173. Retrieved from https://www.researchgate.net/publication/281467810

Nunnally, J. C., \& Bernstein, I. H. (1994). Psychometric theory (3rd ed.). New York, NY: McGraw Hill.

OCDE. (2009). Assurer le bien-être des enfants [Doing better for children]. Paris, France: Editions de l'OCDE.

Petersen, C., Schmidt, S., Power, M., Bullinger, M., \& the DISABKIDS Group. (2005). Development and pilot-testing of a health-related quality of life chronic generic module for children and adolescents with chronic health conditions: A European perspective. Quality of Life Research, 14, 1065-1077. doi:10.1007/s11136-004-2575-Z

Poulin, F., \& Chan, A. (2010). Friendship stability and change in childhood and adolescence. Developmental Review, 30, 257-272. doi:10.1016/j.dr.2009.01.001

Proctor, C. L., Linley, P. A., \& Maltby, J. (2009). Youth life satisfaction: A review of the literature. Journal of Happiness Studies, 10, 583-630. doi:10.1007/s10902-008-9110-9
Proulx, J. (2008). Qualité de vie et participation sociale: deux concepts clés dans le domaine de la déficience intellectuelle. Une recension des écrits [Quality of life and social participation: Two key concepts in the field of intellectual disability. A review of the literature]. (Rapport no. 08-08). Cahiers du Larepps, Québec, Canada: Université du Québec à Montréal.

Rajmil, L., Palacio-Vieira, J. A., Herdman, M., López-Aguilà, S., Villalonga-Olives, E., Valderas, J. M., ... Alonso, J. (2009). Effect on health-related quality of life of changes in mental health in children and adolescents. Health and Quality of Life Outcomes, 7, 1-7. doi:10.1186/1477-7525-7-103

Ravens-Sieberer, U., \& Bullinger, M. (1998). Assessing healthrelated quality of life in chronically ill children with the German KINDL: First psychometric and content analytical results. Quality of Life Research, 7, 399-407. doi:10.1023/ A:1008853819715

Ravens-Sieberer, U., Devine, J., Bevans, K., Riley, A. W., Moon, J., Salsman, J. M., \& Forrest, C. B. (2014). Subjective wellbeing measures for children were developed within the PROMIS project: Presentation of first results. Journal of Clinical Epidemiology, 67, 207-218. doi:10.1016/j.jclinepi. 2013.08.018

Ravens-Sieberer, U., Erhart, M., Wille, N., Wetzel, R., Nickel, J., \& Bullinger, M. (2006). Generic health-related qualityof-life assessment in children and adolescents: Methodological considerations. PharmacoEconomics, 24, 1199-1220. doi:10.2165/00019053-200624120-00005

Rodary, C., Pezet-Langevin, V., \& Kalifa, C. (2001). Qualité de vie chez l'enfant: Qu'est ce qu'un bon outil d'évaluation? [Quality of life in children: What is a 'good' measurement tool?]. Archives de Pédiatrie, 8, 744-750. doi:10.1016/ S0929-693X(00)90309-9

Schalock, R. L. (1993). La qualité de vie: Conceptualisation, mesure et application [Quality of life: Conceptualisation, measurement and application]. Revue Francophone de la Déficience Intellectuelle, 4, 137-151.

Seligman, M. E. P., \& Csikszentmihalyi, M. (2000). Positive psychology: An introduction. American Psychologist, 55, 5-14. doi:10.1037/0003-066X.55.1.5

Shankland, R. (2014). La psychologie positive [Positive psychology] (2nd ed.). Paris, France: Dunod.

Siméoni, M. C., Auquier, P., Delarozière, J. C., \& Béresniak, A. (1999). Evaluation de la qualité de vie chez l'enfant et l'adolescent: Qualité de vie det santé [Assessing quality of life in children and adolescents: Quality of life and health]. La Presse Medicale, 28, 1033-1039.

Stinson, J. N., Kavanagh, T., Yamada, J., Gill, N., \& Stevens, B. (2006). Systematic review of the psychometric properties, interpretability and feasibility of self-report pain intensity measures for use in clinical trials in children and adolescents. Pain, 125, 143-157. doi:10.1016/j.pain.2006.05.006

Tabachnick, B. G., \& Fidell, L. S. (2012). Using multivariate statistics (6th ed.). Boston, MA: Pearson Education.

United Nations. (1989). United Nations convention on the rights of the child. Geneva, Switzerland: Author.

Upton, P., Lawford, J., \& Eiser, C. (2008). Parent-child agreement across child health-related quality of life instruments: A review of the literature. Quality of Life Research, 17, 895913. doi:10.1007/s11136-008-9350-5

Varni, J. W., Seid, M., \& Kurtin, P. S. (2001). PedsQL ${ }^{\mathrm{TM}} 4.0$ : Reliability and validity of the Pediatric Quality of Life 
Inventory ${ }^{\mathrm{TM}}$ Version 4.0 Generic Core Scales in healthy and patient populations. Medical Care, 39, 800-812. doi:10. 1097/00005650-200108000-00006

von Baeyer, C. L., Forsyth, S. J., Stanford, E. A., Watson, M., \& Chambers, C. T. (2009). Response biases in preschool children's ratings of pain in hypothetical situations. European Journal of Pain, 13, 209-213. doi:10.1016/j.ejpain.2008.03. 017

Zabalia, M., \& Corfec, S. (2008). Reconnaissance des émotions et évaluation de la douleur chez des enfants et adolescents porteurs de trisomie 21 [Emotion recognition and pain assessment in children and adolescents with Down syndrome]. Enfance, 60, 357-369. doi:10.3917/enf.604.0357

\section{Appendix 1. List of items of the francophone adaptation of the abbreviated form of the MSLSS.}

Items of the multidimensional scale of life satisfaction by dimension

1. Mes amis sont gentils avec moi (My friends are nice to me)

2. On s'amuse bien avec moi ( $\mathrm{am}$ fun to be around)

3. II y a beaucoup de choses que je peux bien faire (There are lots of things I can do well)

4. J'apprends beaucoup de choses à l'école (I learn a lot at school)

5. J'aime passer du temps avec mes parents (I like spending time with my parents)
Continued.

Items of the multidimensional scale of life satisfaction by dimension

6. Ma famille est mieux que la plupart des autres (My family is better than most)

7. Je pense que je suis beau/belle (I think I am good-looking)

8. Mes amis sont supers (My friends are great)

9. Mes amis $\mathrm{m}$ 'aideront si $\mathrm{j}$ 'en ai besoin (My friends will help me if I need it)

10. Je m'aime bien (I like myself)

11. Il y a pleins de choses amusantes à faire où j'habite (There are lots of fun things to do where I live)

12. Mes amis me traitent bien (My friends treat me well)

13. La plupart des gens $\mathbf{m}^{\prime}$ aiment bien (Most people like me)

14. J'aime être à la maison avec ma famille (I enjoy being at home with my family)

15. Les membres de ma famille s'entendent bien ensemble (My family gets along well together)

16. Je suis content d'aller à l'école (I look forward to going to school)

17. Mes parents me traitent bien (My parents treat me fairly)

18. Je me sens bien à l'école (I like being in school)

19. L'école est intéressante (School is interesting)

20. J'aime les activités proposées à l'école (I enjoy school activities)

21. Les membres de ma famille se parlent gentiment les uns aux autres (Members of my family talk nicely to one another)

22. Je m'amuse beaucoup avec mes amis (I have a lot of fun with my friends)

23. Je fais des choses amusantes avec ma famille (My parents and I do fun things together)

24. J'aime mon quartier (I like my neighbourhood)

25. Je suis une personne agréable (I am a nice person)

26. J'aime essayer faire de nouvelles choses (I like to try new things)

27. Ma maison est agréable (My family's house is nice)

28. J'aime mes voisins (I like my neighbours)

29. J'ai assez d'amis (I have enough friends)

30. J'aime où je vis (I like where I live) 